\title{
HUBUNGAN POLA ASUH ORANG TUA DENGAN MOTIVASI ANAK UNTUK BERSEKOLAH DI KELURAHAN SUKAGALIH KECAMATAN SUKAJADI KOTA BANDUNG
}

\author{
Irma Rostiana ${ }^{1}$, Wilodati ${ }^{2}$, Mirna Nur Alia $A^{3}$ \\ 1SMA PGIl 1 Bandung \\ ${ }^{2}$ Dosen Program Studi Pendidikan Sosiologi \\ ${ }^{3}$ Dosen Program Studi Pendidikan Sosiologi
}

\begin{abstract}
ABSTRAK
Tujuan dari penelitian adalah untuk mengetahui pola asuh yang diterapkan orang tua, mengetahui tingkat motivasi anak untuk bersekolah dan mendapatkan gambaran umum mengenai hubungan pola asuh orang tua dengan motivasi anak untuk bersekolah di Kelurahan Sukagalih Kecamatan Sukajadi Kota Bandung. Metode penelitian yang digunakan adalah survei. Teknik pengumpulan data menggunakan angket dan observasi. Temuan penelitian yaitu, orang tua di kelurahan sukagalih kecamatan sukajadi menerapkan pola asuh otoriter terhadap anak, anak memiliki tingkat motivasi untuk bersekolah dalam kategori tinggi. Pola asuh orang tua memberikan kontribusi terhadap motivasi anak untuk bersekolah di Kelurahan Sukagalih Kecamatan Sukajadi Kota Bandung sebesar 47,78\%. Perolehan nilai korelasi antara pola asuh orang tua dengan motivasi anak untuk bersekolah adalah sebesar 0,691 termasuk dalam kategori hubungan yang sedang, Pola asuh orang tua memiliki hubungan yang signifikan dengan motivasi anak untuk bersekolah di Kelurahan Sukagalih Kecamatan Sukajadi Kota Bandung.
\end{abstract}

Kata kunci: Pola Asuh Orang Tua, Motivasi Bersekolah, Anak

\section{PENDAHULUAN}

Keluarga merupakan tempat dimana individu tumbuh, berkembang dan belajar mengenai nilai-nilai yang dapat membentuk kepribadiannya kelak. Proses belajar tersebut berjalan terus-menerus sepanjang individu tersebut hidup. Ahmadi (2007, hlm. 108) mengemukakan bahwa,

Keluarga adalah wadah yang sangat penting diantara individu dan group, dan merupakan kelompok sosial yang pertama dimana anak-anak menjadi anggotanya, keluarga sudah barang tentu yang pertama-tama pula menjadi tempat untuk mengadakan sosialisasi kehidupan anak-anak.
Keluarga memiliki fungsi tersendiri dalam pembentukan kepribadian seorang individu. Fungsi keluarga yaitu fungsi kasih sayang; fungsi ekonomi; fungsi sosialisasi dan pendidikan; fungsi perlindungan dan fungsi rekreasi (Malihah dan Kolip, 2011, hlm. 270). Proses belajar yang dilalui oleh individu di dalam keluarga merupakan fungsi sosialisasi dan pendidikan yang diterapkan oleh orang tua kepada anak.

Setiap orang tua memiliki cara dan pola tersendiri dalam mengasuh dan membimbing anak, sesuai dengan apa yang mereka kehendaki dan mereka yakini bahwa pola-pola tersebut benar 
untuk menerapkan nilai-nilai kebaikan untuk anak-anaknya. Menurut Bolson (dalam Adrie, Winarti dan Utami, 2001), sedikitnya terdapat tiga pola pengasuhan yang umum diterapkan di masyarakat, yakni pola asuh otoriter, pola asuh demokratis, dan pola asuh permisif.

Pendidikan dibutuhkan setiap individu sepanjang hayat, bukan hanya pendidikan didalam keluarga (pendidikan informal) setiap individu juga harus mendapatkan pendidikan formal yaitu sekolah untuk dapat mengembangkan potensi yang ada dalam dirinya dan dapat hidup mandiri di masyarakat. Namun proses pendidikan tersebut tidak selalu berjalan lancar karena terdapat berbagai hambatan dalam mencapainya, salah satunya adalah rendahnya motivasi/ keinginan individu untuk bersekolah atau melanjutkan pendidikan ke jenjang yang lebih tinggi.

Rendahnya motivasi untuk bersekolah tersebut terjadi karena kurangnya dukungan dari orang terdekat, khususnya orang tua dalam memotivasi anak untuk bersekolah. Berdasarkan penelitian pendahuluan yang dilakukan peneliti di Kelurahan Sukagalih Kecamatan Sukajadi, orang tua cenderung menerapkan pola asuh permisif kepada anak sehingga motivasi anak untuk bersekolah menjadi rendah karena tidak ada atau kurangnya pengawasan dari orang tua. Namun disisi lain, anak yang memiliki motivasi bersekolah yang tinggi mendapatkan dukungan yang baik dari lingkungan mereka, salah satunya adalah orang tua yang selalu memperhatikan kondisi pendidikan anak dan menjadi panutan bagi anak.

\section{HASIL PENELITIAN}

Berdasarkan hasil penelitian penerapan pola asuh orang tua kepada anak (responden) di Kelurahan Sukagalih Kecamatan Sukajadi Kota Bandung menunjukkan bahwa $43 \%$ orang tua menerapkan pola asuh otoriter, $40 \%$ orang tua menerapkan pola asuh demokratis dan sebagian kecil lainnya yaitu sebanyak $17 \%$ orang tua menerapkan pola asuh permisif. Hal tersebut menunjukan bahwa pola asuh yang paling banyak diterapkan oleh orang tua di Kelurahan Sukagalih Kecamatan Sukajadi Kota Bandung adalah pola asuh otoriter yaitu sebanyak $43 \%$ meskipun jumlahnya tidak jauh berbeda dengan pola asuh demokratis sebesar $40 \%$. Maka dapat disimpulkan bahwa pola asuh yang paling banyak diterapkan berdasarkan hasil penelitian pada 108 responden adalah pola asuh otoriter dengan skor rata-rata 83,41.

Adapun hasil penelitian tingkat motivasi anak untuk bersekolah di Kelurahan Sukagalih Kecamatan Sukajadi Kota Bandung menunjukkan bahwa lebih dari setengahnya (56\%) responden memiliki tingkat motivasi bersekolah yang tinggi, $30 \%$ responden memiliki tingkat motivasi sekolah yang sedang dan sebagian kecil (14\%) responden memiliki tingkat motivasi bersekolah yang rendah. Ternyata tingkat motivasi bersekolah di Kelurahan Sukagalih Kecamatan Sukajadi cukup tinggi dengan skor rata-rata 87,05. Motivasi anak untuk bersekolah dapat dikaitkan dengan motivasi anak untuk berprestasi, 
karena kegiatan sekolah berkaitan angsung dengan proses belajar anak. Hasil penelitian ini sejalan dengan pendapat yang dikemukakan Maya (dalam Garliah dan Nasution, 2005, hlm. 45), yang menyatakan bahwa faktor utama yang mempengaruhi motivasi berprestasi individu adalah orang tua dan sekolah. Cara orang tua mendidik anak berhubungan dengan motivasi berprestasi anak, anak yang motivasi berprestasi tinggi memiliki orang tua yang me-reward keberhasian anaknya dan tidak terlalu mengkritik jika anakmengalami kegagalan, sedangkan anak yang motivasi berprestasinya rendah memiliki orang tua yang tidak mau tahu akan keberhasilan anaknya dan memberikan hukuman jika anaknya mengalami kegagalan.

Perolehan nilai korelasi antara pola asuh orang tua dengan motivasi anak untuk bersekolah adalah sebesar 0,691 termasuk dalam kategori hubungan yang sedang. Sedangkan nilai yang diperoleh adalah positif, hal ini menunjukan bahwa hubungan yang terjadi antara kedua variabel adalah searah dimana semakin baik dan sesuai pola asuh yang diterapkan orang tua maka akan semakin tinggi pula motivasi anak untuk bersekolah. Sebaliknya semakin tidak sesuai pola asuh yang diterapkan orang tua maka akan semakin rendah pula motivasi anak untuk bersekolah. Kontribusi yang diberikan variabel independen terhadap variabel dependen adalah sebesar $47,78 \%$ artinya pola asuh orang tua memberikan kontribusi pengaruh sebesar 47,78\% terhadap motivasi anak untuk bersekolah, sedangkan sisanya $100 \%-47,78 \%=$
$52,22 \%$ merupakan pengaruh dari variabel lain yang tidak diteliti. Hasil penelitian ini, sesuai dengan penelitian yang dilakukan Rahmawati mengenai hubungan antara pola asuh orang tua dan kebiasaan belajar terhadap prestasi belajar siswa sd kelas iv semester genap di kecamatan melayajembrana (2014, hlm 7), Berdasarkan hasil uji hipotesis diketahui bahwa terdapat kontribusi yang signifikan antara pola asuh orang tua terhadap prestasi belajar siswa kelas IV semester genap SD Kecamatan Melaya Kabupaten Jembrana tahun pelajaran 2012/2013. Selain itu nilai korelasi tersebut yaitu 0,427 dikategorikan memiliki hubungan yang cukup kuat. Sedangkan kontribusi pola asuh orang tua terhadap prestasi belajar sebesar 18,23\%.

Berdasarkan analisis yang telah dilakukan dengan menggunakan teknik spearmen rank, maka didapatkan hasil penelitian yaitu terdapat hubungan positif yang signifikan antara pola asuh orang tua dengan motivasi anak untuk bersekolah. Dengan nilai signifikansi yang diperoleh sebesar $0,000<0,05$ dan t-hitung 9,88> t-tabel 1,658.

\section{POLA ASUH YANG DITERAPKAN ORANG TUA DI KELURAHAN SUKAGALIH KECAMATAN SUKAJADI KOTA BANDUNG}

Hubungan antara pola asuh orang tua dengan anak di dalam keluarga secara fungsional melibatkan sikap dan perilaku tertentu dari figur ayah dan ibu, baik secara sendiri-sendiri maupun secara bersama-sama. Sikap dan perilaku ini diwujudkan melalui hubungan orang tua dengan anak 
berkenaan dengan tugasnya sebagai orang tua. Secara fungsional, tugas orang tua meliputi upaya mendidik, merawat, melindungi dan mengajar anak-anak agar anak dapat tumbuh dan berkembang secara optimal.

Semua orang tua menginginkan yang terbaik untuk anak-anaknya. Orang tua menginginkan anak mereka memiliki banyak teman, berprestasi di sekolah, menjadi orang yang bertanggung jawab, jujur, menyenangkan, dan berpikir positif mengenai diri sendiri. Memahami perilaku anak dengan menggunakan kekuatan besar yaitu memberi pujian dan pendekatan kepada anak akan membuat anak tersebut menjadi baik. Apalagi pola asuh orang tua yang diberikan dalam membesarkan anak tidak sama. Orang tua menggunakan prinsip yang berbeda-beda sesuai dengan lingkungan mereka masingmasing.

Berdasarkan hasil penelitian yang dibagi kedalam enam aspek yaitu aspek penanaman nilai, penegakkan peraturan, pembentukan sikap, pembatasan pergaulan atau permainan, penghargaan terhadap karya anak dan pemberian hukuman atau ganjaran, menunjukkan bahwa $43 \%$ orang tua responden menerapkan pola asuh otoriter, $40 \%$ orang tua responden menerapkan pola asuh demokratis, dan $17 \%$ orang tua responden menerapkan pola asuh permisif, berdasarkan penyebaran angket yang diberikan kepada 108 responden. Jadi pola asuh yang diterapkan orang tua di kelurahan Sukagalih Kecamatan Sukajadi Kota Bandung berada dalam kategori tinggi atau bersifat otoriter. Sebanyak $43 \%$ responden menerima pola asuh otoriter dari orang tua, artinya, orang tua berada dalam posisi sebagai arsitek. Orang tua dengan cermat memutuskan bagaimana individu harus berperilaku, memberikan hadiah atau hukuman agar perintah orang tua ditaati. Tugas dan kewajiban orang tua tidak sulit, tinggal menentukan apa yang diinginkan dan harus dikerjakan atau yang tidak boleh dilakukan oleh anak-anak mereka.

Menurut Baumrind (Santrock, 2007, hlm. 91) Pola asuh otoriter adalah pola asuh yang bersifat membatasi, memerintah dan menghukum. Pola asuh ini cenderung menerapkan standar yang mutlak harus dituruti anak. Apabila anak tidak mau melakukan apa yang dikatakan oleh orang tua, maka orang tua tidak segan-segan untuk menghukum anaknya. Mereka membatasi dan mengontrol anak mereka dan melakukan komunikasi satu arah. Anak-anak dari orang tua otoriter sering kali tidak kompeten secara sosial, tidak bisa membuat inisiatif untuk beraktivitas, dan komunikasinya buruk.

Pola asuh otoriter memiliki dampak yang cukup baik, dimana jika anak melanggar peraturan atau tidak menuruti perintah yang diberikan orang tua maka anak akan mendapatkan hukuman. Dalam kaitannya dengan pendidikan, jika anak bolos sekolah dan melanggar peraturan sekolah, orang tua akan memberikan hukuman untuk menimbulkan efek jera, sehingga anak tidak lagi melakukan kesalahan yang sama dan akan memperbaiki sikapnya sesuai dengan apa yang diinginkan 
orang tua. Terbukti dari angket hasil penelitian yang telah penulis olah, motivasi sekolah anak (responden) berada dalam kategori tinggi dengan pola asuh otoriter yang diterapkan orang tua. Namun, pola asuh tersebut juga memiliki dampak negatif bagi anak, karena anak memiliki motivasi yang tinggi untuk sekolah sematamata karena perintah yang diberikan orang tua. Anak akan cenderung menjadi penakut dan tidak memiliki inisiatif karena takut untuk mencoba hal-hal baru.

Terdapat $40 \%$ orang tua yang menerapkan pola asuh demokratis pada anak di Kelurahan Sukagalih Kecamatan Sukajadi Kota Bandung berdasarkan hasil pengolahan data yang dilakukan penulis. Pada pola asuh demokratis, orang tua memprioritaskan kepentingan anak. Pola asuh ini mendorong anaknya untuk menjadi independen tetapi masih membatasi dan mengontrol tindakan anaknya. Perbicangan tukar pendapat diperbolehkan dan orang tua bersikap membimbing dan mendukung. Orang tua bersikap rasional, selalu mendasari tindakannya pada rasio atau pemikiran-pemikiran, serta bersikap realistis terhadap kemampuan anak. Anak yang orang tuanya otoritatif sering kali berperilaku kompeten secara sosial dan mereka cenderung mandiri (Baumrind dalam Santrock, 2007, hlm. 91).

Orang tua tidak memaksakan kehendak mereka kepada anaknya, dalam hal pendidikan, orang tua akan memberikan bimbingan dan tuntunan sesuai dengan minat dan bakat yang dimiiki anak, anak tidak memiliki paksaan untuk berprestasi atau bersekolah dari orang tua karena dengan pengertian dan pendekatan yang hangat dari orang tua, anak tahu apa yang harus dilakukannya untuk membahagiakan orang tua tanpa harus dipaksakan. Pola asuh tipe ini bersifat positif karena anak tidak akan merasa tertekan untuk sekolah dan berani bereksplorasi untuk menemukan hal-hal baru dan membuat anak memiliki motivasi untuk bersekolah yang sedang bahkan tinggi.

Pola asuh tipe permisif diterapkan orang tua sebanyak $17 \%$. Hal ini berarti sebanyak $17 \%$ responden menerima pola pengasuhan permisif dari orang tua. Pada pola asuh permisif orang tua biasanya memberikan pengawasan yang sangat longgar, orang tua tidak terlibat aktif dalam kehidupan anak. Mereka memberikan kesempatan pada anaknya untuk melakukan sesuatu tanpa pengawasan dan memberikan sangat sedikit bimbingan kepada anak. Anak dari orang tua yang menerapkan pola asuh tipe ini sering bertindak tidak kompeten secara sosial. Mereka cenderung kurang bisa mengontrol diri, tidak cukup mandiri dan tidak termotivasi untuk berprestasi (Baumrind dalam Santrock, 2007, hlm. 91).

Sesuai dengan penjelasan tersebut, anak memiliki motivasi yang rendah untuk bersekolah, karena orang tua sangat sedikit memberikan bimbingan kepada anak, bahkan terkesan acuh tak acuh dalam hal pendidikan. Hal tersebut terbukti di salah satu RT di Kelurahan Sukagalih Kecamatan Sukajadi Kota Bandung. Anak kurang mendapatkan perhatian 
dan bimbingan dari orang tua, sehingga motivasi mereka untuk bersekolah termasuk dalam kategori rendah. Mereka tidak merasa harus bersekolah atau berprestasi karena orang tua tidak pernah memaksa dan mengharuskan mereka untuk sekolah. Hal tersebut berdampak negatif karena anak bebas melakukan kegiatan tanpa pengawasan orang tua seperti membolos, tidak mengerjakan pekerjaan rumah, berkelahi di sekolah dan sangat sedikit perhatian yang ditunjukkan orang tua. Pada akhirnya pola asuh permisif yang diterapkan orang tua membuat motivasi anak untuk bersekolah menjadi rendah.

\section{TINGKAT MOTIVASI ANAK UNTUK BERSEKOLAH DI KELURAHAN SUKAGALIH KECAMATAN SUKAJADI KOTA BANDUNG}

Berdasarkan hasil penelitian yang dibagi kedalam enam aspek yaitu aspek hasrat atau keinginan berhasil, aspek dorongan atau kebutuhan untuk sekolah, aspek harapan dan cita-cita di masa depan, aspek penghargaan ketika naik kelas atau lulus sekolah, aspek kegiatan yang menarik di sekolah, dan aspek teman bermain di sekolah.

Dari keseluruhan aspek motivasi anak untuk bersekolah di Kelurahan Sukagalih Kecamatan Sukajadi Kota Bandung, dapat dilihat bahwa lebih dari setengahnya (56\%) responden memiliki tingkat motivasi bersekolah yang tinggi, 30\% responden memiliki tingkat motivasi sekolah yang sedang dan sebagian kecil (14\%) responden memiliki tingkat motivasi bersekolah yang rendah. Ternyata tingkat motivasi bersekolah di Kelurahan Sukagalih
Kecamatan Sukajadi cukup tinggi dengan skor rata-rata 87,05.

Motivasi adalah dorongan atau tenaga penggerak untuk melakukan sesuatu. motivasi yang timbul dalam diri individu untuk bersekolah merupakan motivasi yang datang dari dalam diri individu itu sendiri, seperti adanya hasrat atau keinginan untuk berhasil, adanya dorongan dan kebutuhan untuk berprestasi atau sekolah dan adanya cita-cita dimasa depan. Selain motivasi intrinsik, seseorang biasanya juga membutuhkan adanya dukungan atau motif-motif pendorong dari luar (motivasi ekstrinsik) seperti adanya penghargaan ketika naik kelas atau lulus sekolah dan dukungan yang baik melalui pola pengasuhan yang diterapkan orang tua.

Anak dengan motivasi belajar yang tinggi adalah anak yang berusaha membuat aktivitas akademik atau sekolahnya menjadi lebih berarti dan bermakna serta berusaha untuk mengambil keuntungan dari aktivitas akademik tersebut, seperti berprestasi. Peran orang tua adalah faktor penting dalam mengembangkan motivasi bersekolah pada anak. Dengan motivasi yang kuat, maka hambatan apapun yang ditemui anak akan dapat diselesaikan dan secara gigih pula usaha anak untuk mengatasinya.

HUBUNGAN POLA ASUH ORANG TUA DENGAN MOTIVASI ANAK UNTUK BERSEKOLAH DI KELURAHAN SUKAGALIH KECAMATAN SUKAJADI KOTA BANDUNG 
Perolehan nilai korelasi hubungan pola asuh orang tua dengan motivasi anak untuk bersekolah adalah sebesar 0,691. Nilai yang diperoleh adalah positif, hal ini menunjukan bahwa hubungan yang terjadi antara dua variabel adalah searah, dimana semakin baik dan sesuai pola asuh yang diterapkan orang tua akan semakin tinggi juga motivasi anak untuk bersekolah. Sebaliknya, semakin tidak sesuai pola asuh yang diterapkan orang tua akan semakin rendah juga motivasi anak untuk bersekolah. Hubungan pola asuh orang tua dengan motivasi anak untuk bersekolah memberikan kontribusi sebesar $47,78 \%$, sedangkan sisanya $100 \%-47,78 \%=52,22 \%$ merupakan pengaruh dari variabel lain yang tidak diteliti.

Faktor-faktor yang memiliki hubungan terhadap motivasi anak untuk bersekolah menurut Uno (2009, hlm. 23) diantaranya hasrat dan keinginan berhasil, dorongan dan kebutuhan untuk sekolah, harapan dan cita-cita masa depan, penghargaan ketika naik kelas atau lulus sekolah, kegiatan yang menarik di sekolah, dan adanya teman bermain di sekolah. Faktor-faktor tersebut mempengaruhi motivasi anak untuk bersekolah karena apabila faktor-faktor tersebut tidak dimiliki oleh anak maka anak tidak akan memiliki motivasi untuk bersekolah. Untuk itu peran orang tua sangat penting dalam mengembangkan motivasi anak untuk bersekolah. Dari faktor-faktor yang mempengaruhi motivasi anak untuk bersekolah di Kelurahan Sukagalih Kecamatan Sukajadi Kota Bandung dapat diketahui seberapa besar tingkat motivasi anak untuk bersekolah.

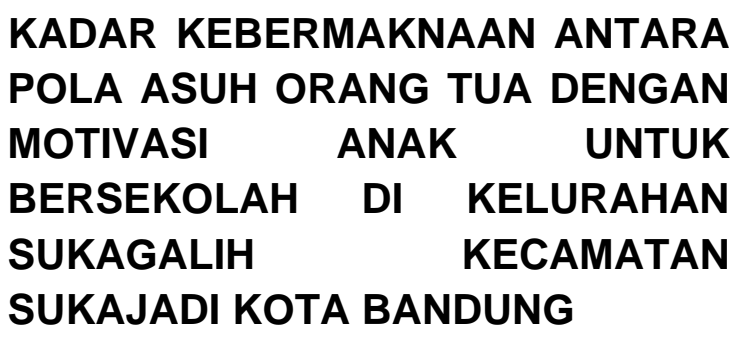

Berdasarkan analisis yang telah dilakukan dengan menggunakan teknik spearmen rank, maka didapatkan hasil penelitian yaitu terdapat hubungan positif yang signifikan antara pola asuh orang tua dengan motivasi anak untuk bersekolah. Dengan nilai signifikansi yang diperoleh sebesar 0,000 0,05 dan t-hitung 9,88 < t-table 1,658. Artinya, semakin baik dan sesuai pola asuh yang diterapkan orang tua kepada anak, maka semakin tinggi pula motivasi anak untuk bersekolah di Kelurahan Sukagalih Kecamatan Sukajadi Kota Bandung. Sebaliknya jika semakin tidak sesuai pola asuh orang tua yang diterapkan kepada anak, maka semakin rendah pula motivasi anak untuk bersekolah di Kelurahan Sukagalih Kecamatan Sukajadi Kota Bandung.

Variabel pola asuh orang tua dengan motivasi anak untuk bersekolah sama-sama kuat. Dalam penelitian ini, pola asuh orang tua memiliki hubungan yang sangat erat dengan motivasi anak untuk bersekolah. Dimana aspek-aspek pola asuh seperti penanaman nilai, penegakkan peraturan dan disiplin, pembentukan sikap dan pemberian teladan, pembatasan pergaulan/permainan, penghargaan terhadap karya anak dan pemberian 
hukuman atau ganjaran tersebutlah yang sangat mempengaruhi motivasi anak untuk bersekolah. Pola asuh orang tua memberikan kontribusi sebesar $47,78 \%$ terhadap motivasi anak untuk bersekolah. Sedangkan faktor lain sebesar 52, 22\% merupakan faktor lain yang tidak diteliti.

\section{PENUTUP}

Sebanyak $43 \%$ orang tua menerapkan pola asuh otoriter kepada responden, sementara $40 \%$ orang tua responden menerapkan pola asuh demokratis, dan sebagian kecil (17\%) orang tua responden menerapkan pola asuh permisif. Artinya, pola asuh yang diterapkan orang tua di Kelurahan Sukagalih cenderung bersifat otoriter, dimana pada setiap aspek pola asuh, orang tua sangat dominan dalam menentukan masa depan anak.

Dari keseluruhan aspek motivasi anak untuk bersekolah di Kelurahan Sukagalih Kecamatan Sukajadi Kota Bandung, dapat disimpulkan bahwa motivasi anak untuk bersekolah di Kelurahan Sukagalih Kecamatan Sukajadi Kota Bandung cukup tinggi.

Pola asuh orang tua memberikan kontribusi terhadap motivasi anak untuk bersekolah di Kelurahan Sukagalih Kecamatan Sukajadi Kota Bandung sebesar $47,78 \%$. Perolehan nilai korelasi antara pola asuh orang tua dengan motivasi anak untuk bersekolah adalah sebesar 0,691 termasuk dalam kategori hubungan yang sedang.

Pola asuh orang tua memiliki hubungan yang signifikan dengan motivasi anak untuk bersekolah di Kelurahan Sukagalih Kecamatan
Sukajadi Kota Bandung, dengan nilai signifikansi yang diperoleh sebesar $0,000<0,05$ dan t-hitung 9,88> t-tabel 1,658. Artinya, semakin baik dan sesuai pola asuh yang diterapkan orang tua, maka semakin tinggi motivasi anak untuk bersekolah di Kelurahan Sukagalih Kecamatan Sukajadi Kota Bandung. Variabel pola asuh orang tua dengan motivasi anak untuk bersekolah sama-sama kuat. Dalam penelitian ini, pola asuh orang tua memiliki hubungan yang sangat erat dengan motivasi anak untuk bersekolah.

\section{DAFTAR PUSTAKA}

Ahmadi, Abu. (2007). Sosiologi Pendidikan. Jakarta: PT. Rineka Cipta.

Malihah, Elly dan Kolip, Usman (2011). Pengantar Antropologi. Bandung: CV. MAULANA MEDIA GRAFIKA.

Santrock, J. W. (2007). Psikologi pendidikan (edisi kedua). Jakarta: Kencana Prenada Media Group.

Uno, Hamzah. B. (2010). Teori Motivasi dan Pengukurannya. Jakarta: Bumi Aksara. 